\title{
Regulation of Vasopressin Gene Expression by cAMP and Glucocorticoids in Parvocellular Neurons of the Paraventricular Nucleus in Rat Hypothalamic Organotypic Cultures
}

\author{
Shinobu Kuwahara, Hiroshi Arima, Ryouichi Banno, Ikuko Sato, Noriko Kondo, and Yutaka Oiso \\ Department of Metabolic Diseases, Field of Internal Medicine, Nagoya University Graduate School of Medicine, Showa-ku, Nagoya 466-8550, Japan
}

\begin{abstract}
Arginine vasopressin (AVP) in the parvocellular neurons of the paraventricular nucleus (PVN) is known to play an important role in the hypothalamo-pituitary-adrenal axis. In the present study, we examined how cAMP and glucocorticoids regulate AVP gene expression in the parvocellular neurons of the PVN in rat hypothalamic organotypic cultures with in situ hybridization. AVP heteronuclear (hn) RNA, an indicator for gene transcription, was induced in the PVN with incubation of forskolin as reported previously, and AVP mRNA was increased by forskolin in the presence of the gene transcription inhibitor 5,6-dichloro-1-D-ribofuranosylbenzimidazole (DRB). These data indicate that cAMP could increase not only gene transcription but also mRNA stability. Dexamethasone treatment, in contrast, significantly decreased AVP mRNA expression levels in the PVN, but this inhibitory action was abolished in the presence of DRB or the sodium channel blocker tetrodotoxin (TTX). However, when the hypothalamic slices were treated with forskolin, dexamethasone decreased AVP mRNA expression even in the presence of DRB and/or TTX. Furthermore, AVP hnRNA expression induced by forskolin was attenuated by dexamethasone treatment in the presence of TTX. These data indicate that dexamethasone could act on AVP cells independently of action potentials to decrease mRNA stability and to suppress AVP gene transcription during stimulation by cAMP. Thus, it was demonstrated that: (1) cAMP upregulates AVP gene transcriptionally and post-transcriptionally, (2) the mode of action of glucocorticoids was dependent on whether the cells were stimulated by cAMP, and (3) the interactions between cAMP and glucocorticoids encompass both gene transcription and mRNA stability.
\end{abstract}

Key words: vasopressin; cAMP; glucocorticoid; transcription; stress; hypothalamus

\section{Introduction}

Physical or psychological stressors are known to activate the hypothalamo-pituitary-adrenal axis, which allows the organisms to adapt to changes in the environment (Swanson and Sawchenko, 1983; Kiss and Aguilera, 1993; Aguilera, 1994). The corticotropin-releasing hormone (CRH) and arginine vasopressin (AVP) in the parvocellular neurons of the paraventricular nucleus (PVN) are the major regulators of ACTH secretion (Gillies et al., 1982; Rivier et al., 1984; Antoni, 1986). AVP is a weak ACTH secretagogue on its own but potentiates the stimulatory effects of CRH on ACTH release in the corticotroph (Gillies et al., 1982; Rivier et al., 1984; Aguilera, 1994).

Several lines of evidence suggest that AVP gene is upregulated by cAMP. The promoter of AVP gene contains cAMP response element (CRE), and the promoter activities of transfected AVP gene are upregulated with cAMP in cell lines (Pardy et al., 1992;

\footnotetext{
Received May 23, 2003; revised Sept. 6, 2003; accepted Sept. 19, 2003.

This work was supported in part by a grant-in aid for scientific research (B) from the Japanese Society for Promotion of Science, Japan (14370325).

Correspondence should be addressed to Dr. H. Arima, Department of Metabolic Diseases, Field of Internal Medicine, Nagoya University Graduate School of Medicine, 65 Tsurumai-cho, Showa-ku, Nagoya 466-8550, Japan. E-mail: arima105@med.nagoya-u.ac.jp.

Copyright $\odot 2003$ Society for Neuroscience $\quad$ 0270-6474/03/2310231-07\$15.00/0
}

Iwasaki et al., 1997). Furthermore, we have shown recently that AVP heteronuclear (hn) RNA, an indicator for gene transcription, is increased with forskolin (FSK) in parvocellular neurons of the PVN in hypothalamic organotypic cultures (Arima et al., 2001). These data provide convincing evidence that cAMP increases AVP gene transcription. In addition, cAMP reportedly enhances the polyadenylation of AVP mRNA, which is related to the stability of mRNA (Emanuel et al., 1998), and endogenous AVP mRNA expression is increased with incubation of cAMP in dispersed cultures of rat hypothalamus (Oeding et al., 1990; Emanuel et al., 1992). Because the amount of mRNA depends on the balance between gene transcription and degradation, these data suggest that cAMP could increase AVP gene transcription and/or mRNA stability.

AVP and CRH in the parvocellular neurons of the PVN are negatively regulated by glucocorticoids (Davis et al., 1986; Sawchenko, 1987a). The removal of the negative feedback action of glucocorticoids by adrenalectomy resulted in the upregulation of the CRH and AVP gene expression in the parvocellular neurons (Davis et al., 1986; Kovács et al., 1986, 2000; Kovács and Mezey, 1987; Sawchenko, 1987a,b; Ma and Aguilera, 1999). The glucocorticoid receptors (GRs) are expressed in the parvocellular neurons of the PVN (Fuxe et al., 1985; Uht et al., 1988), and the 
implantation of glucocorticoid at the PVN level can prevent the expected adrenalectomy-induced expression of CRH and AVP in the parvocellular PVN neurons (Kovács et al., 1986; Kovács and Mezey, 1987; Sawchenko, 1987b). In primary cultures of the hypothalamus, glucocorticoids have been shown to inhibit synthesis and secretion of CRH and AVP (Hu et al., 1992; Hellbach et al., 1998; Kim et al., 2001). Although these data suggest that glucocorticoids act at hypothalamic levels to suppress AVP synthesis and release, it remains to be established whether glucocorticoids act directly on parvocellular neurons or indirectly through neural transmission. It is also unclear whether glucocorticoids affect gene transcription or post-transcriptional levels such as mRNA stability.

To address these issues, we investigated the effects of cAMP and glucocorticoids on AVP gene transcription as well as mRNA stability using rat hypothalamic organotypic cultures and in situ hybridization.

\section{Materials and Methods}

Slice-explant culture procedure. Hypothalamic slice-explant cultures were performed as described previously (House et al., 1998; Arima et al., 2001). Seven-day-old Sprague Dawley rats (Chubu Science Materials, Nagoya, Japan) (lights on from 9:00 A.M. to 9:00 P.M.) were killed by decapitation between 9:00 A.M. and 12:00 A.M., and hypothalamic tissues were sectioned at $350 \mu \mathrm{m}$ thickness on a Mcllwain tissue chopper (Mickle Laboratory Engineering Co., Surrey, UK). Three coronal slices containing the PVN, suprachiasmatic nucleus (SCN) and supraoptic nucleus (SON) were separated and placed in HBSS (Invitrogen, Grand Island, NY) enriched with glucose. Selected sections were trimmed dorsally above the top of the third ventricle and laterally from the SON. Explants from individual rats were placed on $0.4 \mu \mathrm{m}$ Millicell-CM filter inserts (pore size, $0.4 \mu \mathrm{m}$; diameter, $30 \mathrm{~mm}$; Millipore, Billerica, MA), and each filter insert was placed in a Petri dish $(35 \mathrm{~mm})$ containing $1.1 \mathrm{ml}$ of culture medium. Cultures were performed at $36.5^{\circ} \mathrm{C}$ in $5 \% \mathrm{CO}_{2}-$ enriched air, under stationary conditions.

Medium and incubation. The standard culture medium was composed of 50\% Earle's MEM (Invitrogen), 25\% heat-inactivated horse serum, $25 \%$ HBSS (Invitrogen), $25 \mathrm{U} / \mathrm{ml}$ penicillin-streptomycin (Invitrogen), $1 \mathrm{~mm}$ L-glutamine (Invitrogen), and $0.5 \%$ glucose. The serum-free medium was composed of Neurobasal-A medium (Invitrogen) supplemented with 2\% B27 (Invitrogen), 1 mm sodium pyruvate (Invitrogen), 2 mM Gluta MAX I (Invitrogen), 10 mM HEPES (Invitrogen), 0.075\% sodium bicarbonate solution (Invitrogen), $0.5 \%$ glucose, and $100 \mathrm{U} / \mathrm{ml}$ penicillin-streptomycin. Cultures were maintained in the standard medium for $12 \mathrm{~d}$, and the medium was changed to defined serum-free medium for an additional $5 \mathrm{~d}$ before subjecting slices to different experimental conditions. The medium was changed three times per week. All experiments were performed on day 17.

Effects of cAMP on AVP mRNA expression. To examine the effects of cAMP on AVP mRNA expression in hypothalamic organotypic cultures, slices were incubated with $10 \mu \mathrm{M}$ forskolin or vehicle [0.1\% dimethylsulfoxide (DMSO); Sigma, St. Louis, MO] for $24 \mathrm{hr}$. To block gene transcription, slices were incubated with $150 \mu \mathrm{M}$ 5,6-dichloro-1-Dribofuranosylbenzimidazole (DRB) (Sigma) dissolved in 0.1\% DMSO for $24 \mathrm{hr}$ (Maurer and Wray, 1997a,b). To determine the effects of cAMP on AVP mRNA expression without gene transcription, slices were pretreated with DRB for $1 \mathrm{hr}$ and incubated with $10 \mu \mathrm{M}$ forskolin or vehicle in the presence of DRB for an additional $24 \mathrm{hr}$. To determine whether the effects of forskolin on AVP mRNA expression were dependent on action potentials, slices were preincubated with the sodium channel blocker tetrodotoxin (TTX) (1 $\mu \mathrm{M}$; Sankyo, Tokyo, Japan) for $30 \mathrm{~min}$ to block synaptic transmission (Wray et al., 1991) and incubated with forskolin or vehicle in the presence of TTX and DRB for an additional $24 \mathrm{hr}$.

Effects of glucocorticoids on AVP mRNA expression. To examine the effects of glucocorticoids on AVP mRNA expression in hypothalamic organotypic cultures, slices were incubated with 100 nм dexamethasone (DEX) or vehicle $(0.1 \%$ ethanol) for $24 \mathrm{hr}$. To determine whether the effects of DEX were dependent on action potentials, slices were preincubated with TTX and then incubated with DEX or vehicle in the presence of TTX for an additional $24 \mathrm{hr}$. To assess the effects of DEX on AVP mRNA in the absence of transcription, slices were pretreated with DRB for $1 \mathrm{hr}$ and incubated with $100 \mathrm{~nm}$ DEX or vehicle in the presence of DRB for an additional $24 \mathrm{hr}$.

Interaction of cAMP and glucocorticoids on AVP mRNA expression. To determine the possible interaction between cAMP and glucocorticoids on the regulation of AVP mRNA expression, slices were pretreated with $100 \mathrm{~nm}$ DEX or vehicle for $1 \mathrm{hr}$ and incubated with $10 \mu \mathrm{m}$ forskolin in the presence of DEX or vehicle for an additional $24 \mathrm{hr}$. To assess the effects of glucocorticoids on AVP mRNA stability stimulated by cAMP, slices were pretreated with DRB for $1 \mathrm{hr}$ and incubated with $10 \mu \mathrm{M}$ forskolin or vehicle in the presence of DRB and DEX, or DRB and vehicle for an additional $24 \mathrm{hr}$. To determine whether the effects of DEX on AVP mRNA stability are dependent on action potentials, slices were pretreated with TTX for $30 \mathrm{~min}$ and incubated with DEX or vehicle in the presence of forskolin, DRB, and TTX for an additional $24 \mathrm{hr}$.

Interaction of cAMP and glucocorticoids on AVP hnRNA expression. Slices were pretreated with $100 \mathrm{~nm}$ DEX or vehicle for $1 \mathrm{hr}$ and incubated with $10 \mu \mathrm{M}$ forskolin in the presence of DEX or vehicle for an additional $3 \mathrm{hr}$ as a means to assess possible effects of glucocorticoids on AVP gene transcription stimulated by cAMP. Then, to assess whether the effects of DEX were dependent on action potentials, slices were pretreated with TTX for $30 \mathrm{~min}$ and incubated with forskolin in the presence of TTX and DEX or TTX and vehicle for an additional $3 \mathrm{hr}$.

In situ hybridization and quantification. Slices were fixed between 9:00 A.M. and 12:00 A.M. with 4\% formaldehyde in PBS for $30 \mathrm{~min}$, washed twice in PBS, mounted onto poly-L-lysine-coated slides, dried, and kept at $-80^{\circ} \mathrm{C}$ until processed for in situ hybridization.

The rat AVP exonic probe (kindly provided by Drs. Susan Wray and Harold Gainer, National Institute of Neurological Disorders and Stroke, National Institutes of Health, Bethesda, MD) was a $200 \mathrm{bp}$ fragment of the rat AVP cDNA subcloned into pSP64 and linearized by BamHI. The rat AVP intronic probe (kindly provided by Dr. Thomas G. Sherman, Georgetown University, Washington, DC) was a 735 bp fragment of intron 1 of the rat AVP gene subcloned into pGEM-3 and linearized by HindIII. High specific antisense probes were synthesized using $55 \mu \mathrm{Ci}$ $\left[{ }^{35} \mathrm{~S}\right] \mathrm{UTP}$ and $171 \mu \mathrm{Ci}\left[{ }^{35} \mathrm{~S}\right] \mathrm{CTP}$ (PerkinElmer Life Sciences, Natick, MA), a Riboprobe Combination System (Promega, Madison, WI), 15 U of RNAsin, $1 \mu \mathrm{g}$ of linearized template, and $15 \mathrm{U}$ of T7 RNA polymerase for intronic probe or $15 \mathrm{U}$ of SP6 RNA polymerase for exonic probe. After 60 min of incubation at $42^{\circ} \mathrm{C}$, the cDNA template was digested with DNase for $10 \mathrm{~min}$ at $37^{\circ} \mathrm{C}$. Radiolabeled RNA products were purified using quick-spin columns (Roche Diagnostics, Indianapolis, IN), precipitated with ethanol, and resuspended in $100 \mu \mathrm{l}$ of $10 \mathrm{~mm}$ Tris- $\mathrm{HCl}, \mathrm{pH}$ 7.5 , containing $20 \mathrm{~mm}$ DTT.

Prehybridization, hybridization, and posthybridization procedures were performed as described previously (Arima and Aguilera, 2000). In brief, after thawing at room temperature, sections were acetylated with $0.25 \%$ acetic anhydride in $0.1 \mathrm{~m}$ triethanolamine and $0.9 \% \mathrm{NaCl}, \mathrm{pH} 8$, for $10 \mathrm{~min}$ at room temperature. Sections were then dehydrated in 70,80 , 95 , and $100 \%$ ethanol, delipidated in chloroform, and hybridized overnight at $55^{\circ} \mathrm{C}$ with $2 \times 10^{6} \mathrm{cpm}$ of ${ }^{35} \mathrm{~S}$-labeled probes in $90 \mu \mathrm{l}$ of hybridization buffer (50\% formamide, $200 \mathrm{~mm} \mathrm{NaCl}, 2.5 \mathrm{~mm}$ EDTA, 10\% dextran sulfate, $250 \mu \mathrm{g} / \mathrm{ml}$ yeast tRNA, $50 \mathrm{~mm}$ dithiothreitol, and $1 \times$ Denhardt's solution). At the end of incubation, sections were subjected to consecutive washes in $4 \times$ standard saline citrate (SSC) for $15 \mathrm{~min}$ at room temperature and $50 \%$ formamide and $250 \mathrm{~mm} \mathrm{NaCl}$ containing dithiothreitol for $15 \mathrm{~min}$ at $60^{\circ} \mathrm{C}$. After treatment with RNase A $(20$ $\mu \mathrm{g} / \mathrm{ml}$ ) for $30 \mathrm{~min}$ at $37^{\circ} \mathrm{C}$, sections were washed with $2 \times \mathrm{SSC}, 1 \times \mathrm{SSC}$, and $0.5 \times$ SSC for $5 \mathrm{~min}$ at room temperature followed by washes with $0.1 \times$ SSC containing dithiothreitol for $15 \mathrm{~min}$ at $50^{\circ} \mathrm{C}$ and $0.1 \times$ SSC to cool at room temperature and with $70 \%$ ethanol for $15 \mathrm{sec}$. After the final washes, sections were air-dried and exposed to Kodak (Rochester, NY) BioMax MR films for various periods yielding appropriate signal intensities (usually $1 \mathrm{~d}$ for mRNA and 3-5 d for hnRNA). The optical densities (ODs) of the autoradiographs were quantified using a computer image analysis system (Imaging Research, St. Catharines, Ontario, Canada) and 

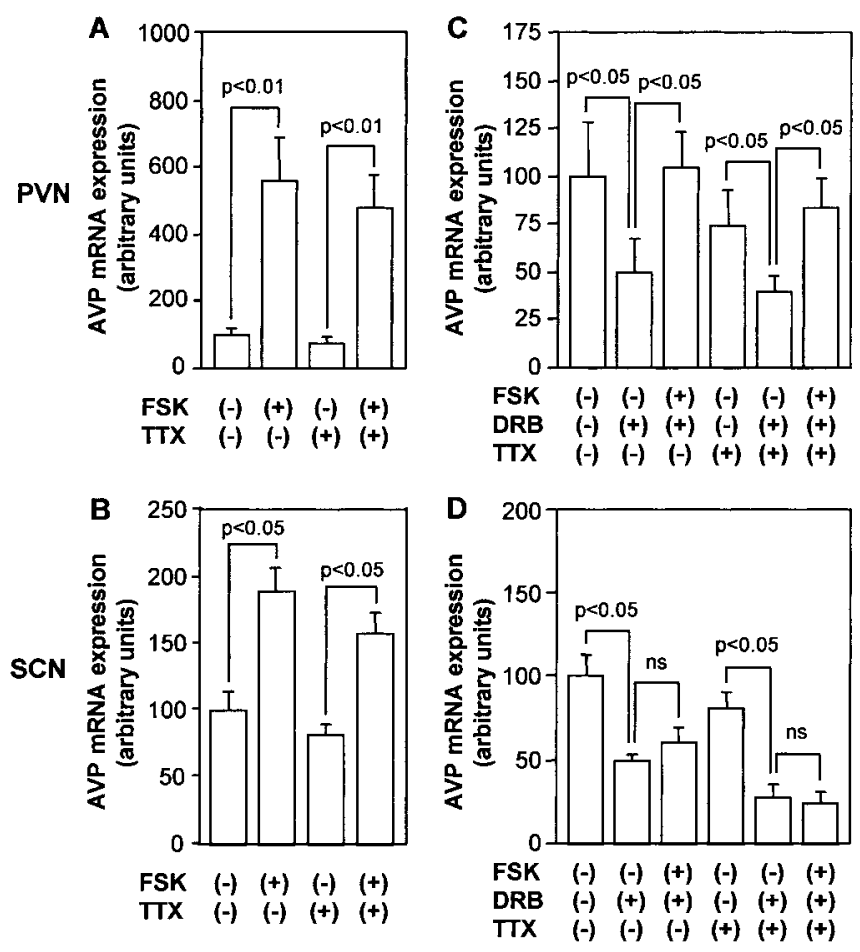

Figure 1. Effects of FSK on AVP mRNA expression in organotypic cultures. Slices were incubated with $10 \mu \mathrm{m}$ FSK or vehicle $(0.1 \%$ DMSO) for $24 \mathrm{hr}$ in the presence or absence of $1 \mu \mathrm{m} \mathrm{TTX}$ $(A, B)$. Slices were also incubated with $F S K$ or vehicle for $24 \mathrm{hr}$ in the presence or absence of 150 $\mu \mathrm{m}$ DRB and/or TTX $(C, D)$. AVP mRNA expression was examined in the PVN $(A, C)$ and $S C N(B, D)$. Statistical analyses were performed with ANOVA followed by Fisher's PLSD test. The mean AVP mRNA expression levels in control are expressed as 100 . The results are expressed as means \pm $\operatorname{SE}(n=10)$. ns, Not significant.

the public domain NIH Image program (developed at the National Institutes of Health, and made available for downloading at http://rsb.info.nih.gov/nih-image).

Changes in AVP mRNA and AVP hnRNA levels after treatment were quantified by measurements of the integrated OD $(\mathrm{OD} \times$ area $)$ of the film images. The total sum of OD signals of AVP mRNA and AVP hnRNA in the bilateral PVN and SCN in the sections from each rat was used in the analysis. The data on expression levels were normalized with control cultures, and statistical analyses were performed with ANOVA followed by Fisher's protected least significant difference (PLSD) test. Results are expressed as means $\pm \mathrm{SE}$, and differences were considered statistically significant at $p<0.05$.

\section{Results}

\section{Effects of cAMP on AVP mRNA expression}

As reported previously (Arima et al., 2001), only parvocellular neurons could survive well in the organotypic culture under the conditions used. Thus, the AVP mRNA was expressed in the SCN and PVN but not in the SON under basal conditions (data not shown). Incubation with TTX alone did not significantly affect AVP mRNA expression levels in the PVN or SCN (Fig. 1). AVP mRNA expression levels in the PVN and SCN were increased significantly with forskolin treatment (Fig. 1), indicating that cAMP upregulates AVP mRNA expression in both nuclei. Because we have already shown that forskolin could increase AVP gene transcription in PVN and SCN in hypothalamic organotypic cultures (Arima et al., 2001, 2002), we next examined whether forskolin may also affect mRNA stability using DRB, which has been shown to inhibit gene transcription (Maurer and Wray, 1997a,b). Treatment with DRB for $24 \mathrm{hr}$ almost completely abolished the basal AVP hnRNA expression in the SCN as well as the
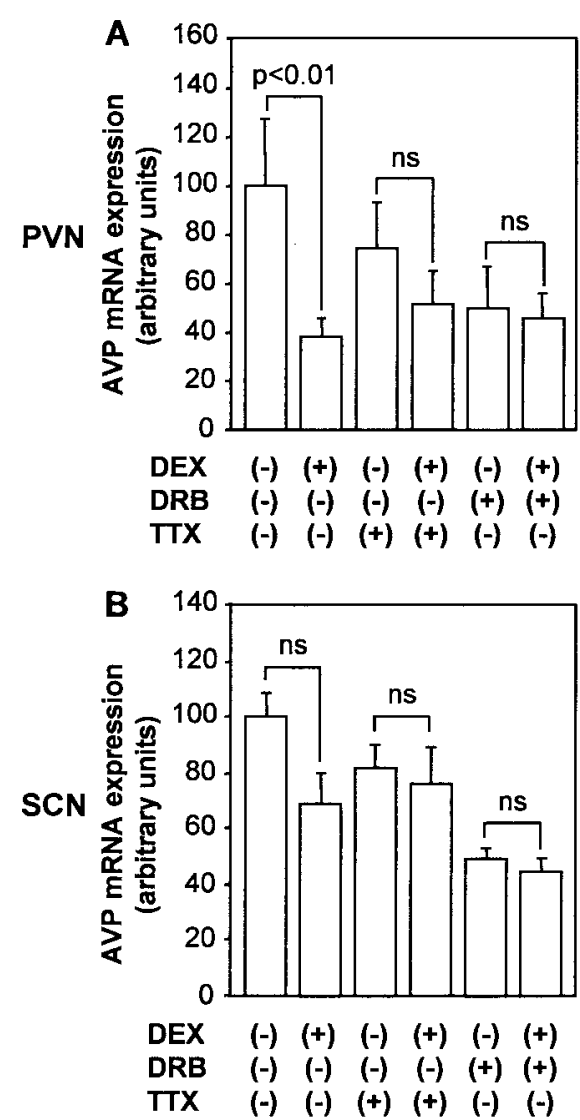

Figure 2. Effects of DEX on AVP mRNA expression in organotypic cultures. Slices were incubated with $100 \mathrm{~nm}$ DEX or vehicle ( $0.1 \%$ ethanol) for $24 \mathrm{hr}$ in the presence or absence of $1 \mu \mathrm{M}$ TTX and/or $150 \mu \mathrm{m}$ DRB. AVP mRNA expression was examined in the PVN $(A)$ and SCN $(B)$. Statistical analyses were performed with ANOVA followed by Fisher's PLSD test. The mean AVP mRNA expression levels in control are expressed as 100 . The results are expressed as means \pm SE $(n=$ 10). ns, Not significant.

forskolin-stimulated AVP hnRNA expression in PVN and SCN (data not shown), and quantitative analyses with prolonged exposure of the autoradiographs revealed that AVP hnRNA levels were $<1 \%$ in DRB compared with control. Incubation with DRB for $24 \mathrm{hr}$ significantly decreased AVP mRNA expression in the absence or presence of TTX in both PVN and SCN (Fig. 1C,D). In the presence of DRB, FSK treatment increased AVP mRNA levels significantly in the PVN but not in the SCN (Fig. 1C,D), suggesting that AVP mRNA stability in the PVN is increased by cAMP. To determine whether the action of forskolin on AVP mRNA stability is dependent on action potentials, we did so in the presence of TTX. Forskolin treatment increased AVP mRNA expression in DRB significantly in the PVN but not in the SCN even in the presence of TTX (Fig. 1C,D), indicating that the action of FSK on AVP mRNA stability in the PVN is independent of action potentials.

\section{Effects of glucocorticoids on AVP mRNA expression}

AVP mRNA expression levels in the PVN but not in the SCN were decreased significantly with incubation of DEX for $24 \mathrm{hr}$ in the absence of TTX (Fig. 2A,B), suggesting that glucocorticoids negatively regulate AVP gene expression exclusively in the PVN. In contrast, AVP mRNA expression levels in the PVN or SCN were not decreased significantly by incubation with DEX in the presence of TTX (Fig. 2A,B). These results suggest that the inhibitory action of DEX on AVP mRNA expression is dependent on action 

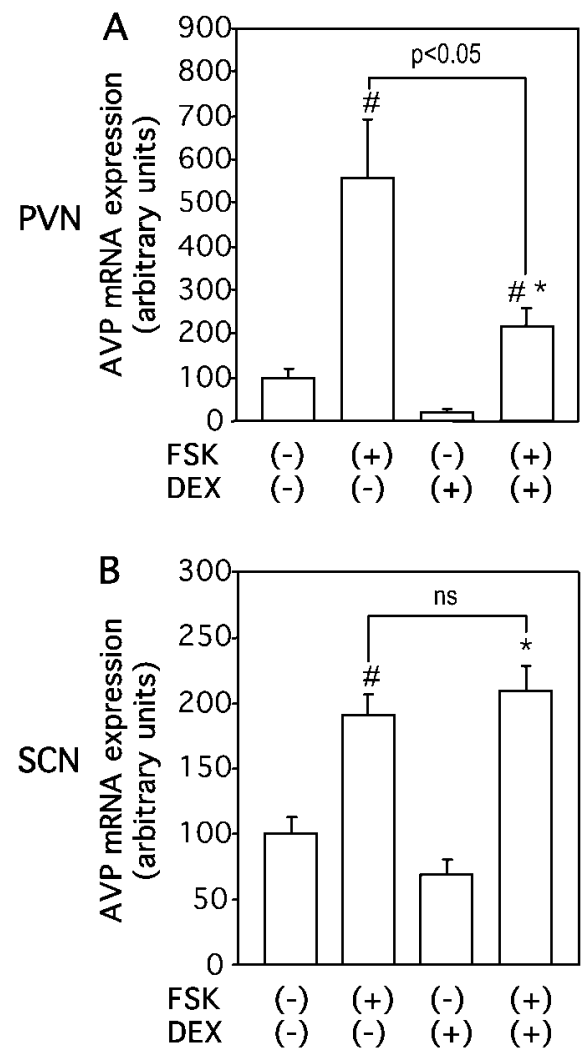

Figure 3. Effects of DEX on FSK-stimulated AVP mRNA expression in organotypic cultures. Slices were incubated with $10 \mu \mathrm{m}$ FSK or vehicle (0.1\% DMSO) for $24 \mathrm{hr}$ in the presence or absence of $100 \mathrm{~nm}$ DEX. AVP mRNA expression was examined in the PVN $(A)$ and SCN $(B)$. Statistical analyses were performed with ANOVA followed by Fisher's PLSD test. The mean AVP mRNA expression levels in control are expressed as 100 . The results are expressed as means \pm SE $(n=10)$. ns, Not significant. ${ }^{\#} p<0.01$ versus values in FSK $(-)$, DEX $(-) ;{ }^{*} p<0.01$ versus values in $\mathrm{FSK}(-), \mathrm{DEX}(+)$.

potentials. The effects of DEX were also examined in the presence of DRB to determine whether they could decrease AVP mRNA expression in the absence of gene transcription. As shown in Figure 2, DEX treatment did not affect AVP mRNA levels significantly in the PVN or SCN in the presence of DRB.

\section{Interaction of cAMP and glucocorticoids on AVP gene expression}

To elucidate how glucocorticoids interact with cAMP to regulate AVP gene expression, we first examined the effects of DEX on AVP mRNA expression stimulated by forskolin. As shown in Figure 3, incubation with DEX significantly but not completely decreased forskolin-stimulated AVP mRNA expression in the PVN but not in the SCN. To determine whether glucocorticoids could inhibit AVP gene transcription induced by cAMP, we examined the effects of DEX on AVP hnRNA expression induced by forskolin. DEX treatment reduced forskolin-induced AVP hnRNA expression in PVN to $33 \%$ (Fig. $4 A$ ). In contrast, DEX treatment did not significantly affect the AVP hnRNA expression in the SCN (Fig. $4 B$ ), suggesting that the action of DEX is specific to the PVN. DEX treatment also significantly decreased forskolin-induced AVP hnRNA levels in the PVN but not in the SCN in the presence of TTX (Fig. 4C,D), indicating that the inhibitory action of DEX on AVP hnRNA expression in the PVN was independent of action potentials. Next, the effects of DEX on AVP mRNA expression stimulated by forskolin in the presence of
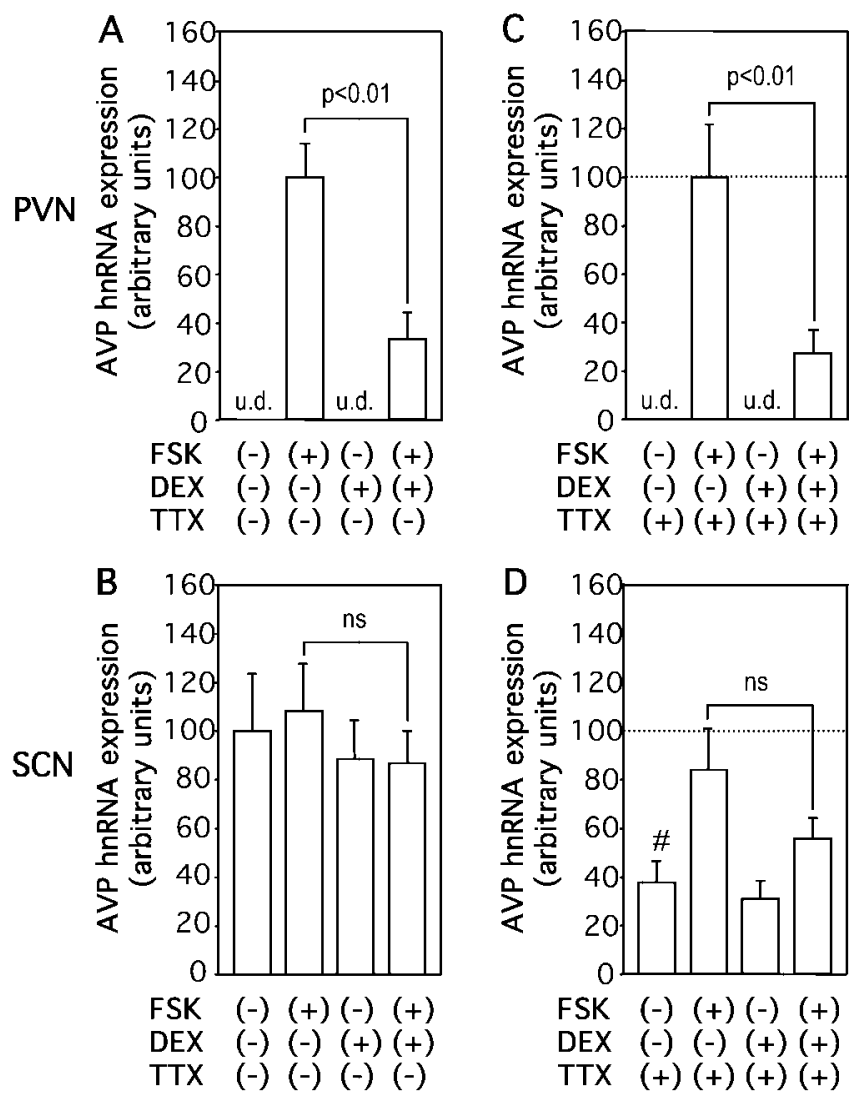

Figure 4. Effects of DEX on FSK-stimulated AVP hnRNA expression in organotypic cultures. Slices were incubated with $10 \mu \mathrm{m}$ FSK or vehicle (0.1\% DMSO) for $3 \mathrm{hr}$ in the presence or absence of $100 \mathrm{~nm}$ DEX and/or $1 \mu \mathrm{m}$ TTX. AVP hnRNA expression was examined in the PVN $(A, C)$ and SCN $(B, D)$. Statistical analyses were performed with ANOVA followed by Fisher's PLSD test. The mean FSK-stimulated AVP hnRNA expression levels in the absence of TTX are expressed as 100 for PVN $(A)$ and shown as a dotted line in C. However, the mean AVP hnRNA levels in control are expressed as 100 for $\operatorname{SCN}(B)$ and shown as a dotted line in $D$. As reported previously (Arima et al., 2001, 2002), TTX treatment alone did not significantly affect AVP hnRNA expression induced by FSK in PVN ( $C$, whereas it significantly decreased $\left({ }^{\#} p<0.05\right)$ the basal AVP hnRNA expression in SCN $(D)$. The results are expressed as means \pm SE $(n=10)$. ns, Not significant; u.d., undetectable.

DRB were investigated to determine whether glucocorticoids could affect mRNA stability increased by cAMP. In contrast to the basal conditions (Fig. 2), DEX treatment significantly decreased forskolin-stimulated AVP mRNA expression in the presence of DRB in the PVN but not in the SCN (Fig. 5A,B). DEX treatment with DRB also significantly decreased the forskolinstimulated AVP mRNA expression in the PVN but not in the SCN in the presence of TTX (Fig. 5C,D), indicating that the action is independent of action potentials. Representative autoradiographs are shown in Figure 6.

\section{Discussion}

In the present study, we examined AVP gene regulation by cAMP and glucocorticoids in the parvocellular neurons of the PVN in organotypic cultures. Our data showed that cAMP could increase not only AVP gene transcription but also mRNA stability and that glucocorticoids inhibited gene transcription and decreased mRNA stability. Our data also suggest that cAMP and glucocorticoids interacted to regulate AVP gene expression in the parvocellular neurons of the PVN.

In previous studies (Arima et al., 2001, 2002), we have shown that: (1) AVP hnRNA is expressed robustly in the SCN but not in 

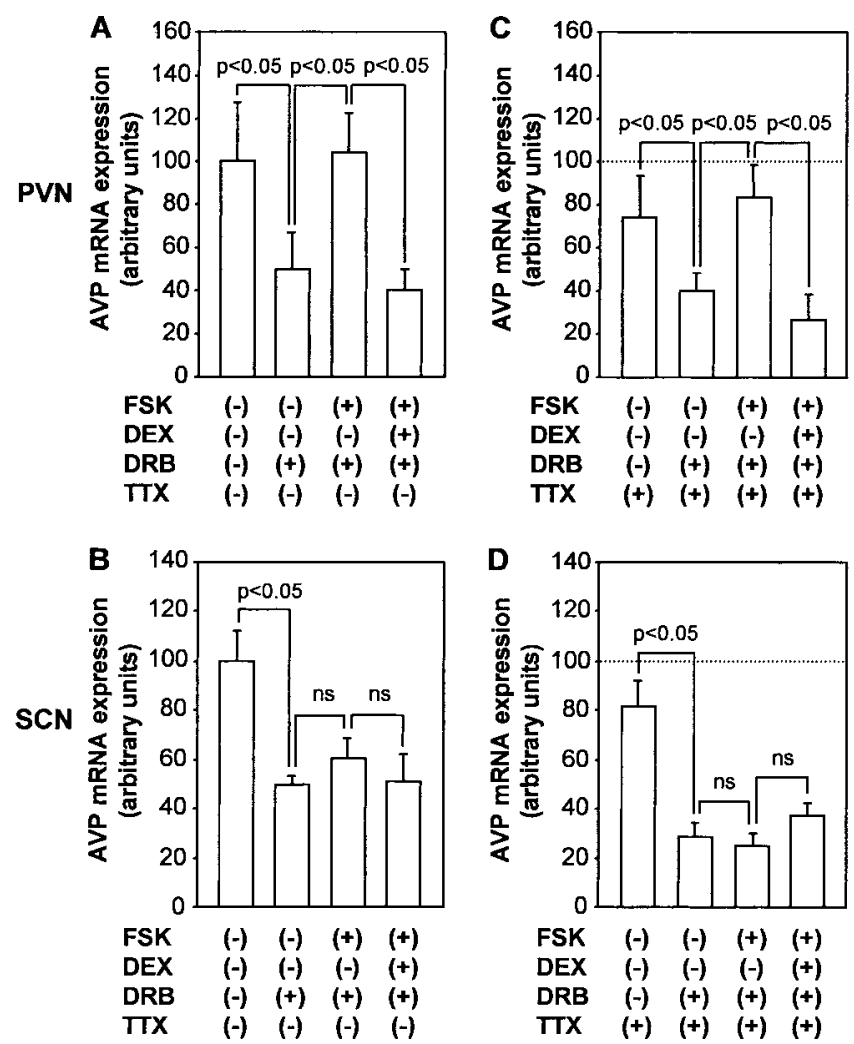

Figure 5. Effects of DEX on FSK-stimulated AVP mRNA stability in organotypic cultures. Slices were incubated with $150 \mu \mathrm{m} \mathrm{DRB}, 10 \mu \mathrm{m}$ FSK, $100 \mathrm{~nm}$ DEX, or vehicle (0.1\% ethanol) for $24 \mathrm{hr}$ in the absence $(A, B)$ or presence $(C, D)$ of $1 \mu \mathrm{m}$ TTX. AVP mRNA expression was examined in the $\operatorname{PVN}(A, C)$ and SCN $(B, D)$. Statistical analyses were performed with ANOVA followed by Fisher's PLSD test. The mean AVP mRNA expression levels in the PVN and SCN in control are expressed as 100. In $C, D$, the control values are shown by dotted lines. ns, Not significant.

the PVN under basal conditions, (2) forskolin treatment induced AVP hnRNA expression in the PVN, and the action was independent of action potentials, (3) effects of forskolin on AVP hnRNA expression in the SCN were dependent on time examined, and (4) TTX treatment decreased AVP hnRNA expression levels in the SCN and forskolin increased AVP gene transcription in TTX. In the present study, we extended the findings and showed that the increased gene transcription is accompanied by increased mRNA expression in the SCN and PVN (Fig. 1). Furthermore, we demonstrated that forskolin also increased AVP mRNA stability in the PVN, and that the action is independent of action potentials (Fig. 1). Song et al. (2001) showed in explants of the hypothalamo-neurohypophyseal system that contained the SON and SCN but not the PVN that AVP mRNA expression was decreased by cAMP in the presence but not in the absence of actinomycin. This was interpreted as indicating that cAMP increased AVP mRNA turnover. In the present study, the stimulatory effects of forskolin on AVP mRNA stability were seen in the PVN but not in the SCN (Fig. 1C,D). Therefore, the discrepancy between studies might be attributable to the differential regulation of AVP gene between magnocellular and parvocellular neurons.

AVP mRNA as well as hnRNA expression is extremely low in the parvocellular neurons of the PVN in basal conditions in vivo (Kovács et al., 1986, 2000; Sawchenko, 1987a,b). However, once circulating glucocorticoids are removed by adrenalectomy, the robust expression of both mRNA and hnRNA is induced, suggesting the tonic inhibition of AVP gene expression by glucocorticoids (Kovács et al., 1986, 2000; Sawchenko, 1987a,b). Although glucocorticoids may act on extrahypothalamic sites such as the hippocampus to regulate AVP and CRH gene expression in the PVN (Kovács and Mezey, 1987; Sapolsky et al., 1990; Herman et al., 1992), our data showed that glucocorticoids act at hypothalamic levels to suppress AVP gene expression. Furthermore, experiments using TTX suggest that glucocorticoids inhibit AVP gene expression in the PVN indirectly through neural transmission if cells are not stimulated by cAMP (Fig. $2 A$ ). Indirect effects of glucocorticoids on AVP gene expression were also suggested in a previous paper, in which adrenalectomy-induced AVP mRNA expression in the parvocellular neurons was modulated by synaptic inputs (Baldino et al., 1988). One of the candidates for the inhibitory neurotransmitters is GABA, which is shown to exist throughout the hypothalamus (Decavel and van den Pol, 1992; Keim and Shekhar, 1996; Miklós and Kovács, 2002). GABA inhibits the release of CRH and/or AVP in vivo and in vitro (Plotsky et al., 1987; Calogero et al., 1988; Hillhouse and Milton, 1989; Otake et al., 1991; Miklós and Kovács, 2002), whereas GABA $_{\mathrm{A}}$ antagonists increase $\mathrm{CRH}$ and AVP expression in the parvocellular PVN neurons (Cole and Sawchenko, 2002). Therefore, it is possible that DEX treatment in the present study suppressed AVP mRNA expression by inducing the release of GABA from adjacent neurons, although further study would be necessary to prove this hypothesis.

Several stressors such as restraint and ether are known to stimulate AVP as well as CRH expression in the parvocellular neurons of the PVN in vivo (deGoeij et al., 1991, 1992; Kiss and Aguilera, 1993; Aguilera, 1994; Kovács et al., 2000). In these conditions, circulating glucocorticoids are elevated (deGoeij et al., 1991; Kiss and Aguilera, 1993; Aguilera et al., 1994) and are supposed to counter-regulate the AVP and CRH expression. In the present study, we have shown that AVP expression induced by cAMP is attenuated by glucocorticoids. In contrast to the experimental conditions without forskolin (Fig. 2A), glucocorticoids could act on AVP cells independently of action potentials to inhibit the gene transcription stimulated by cAMP (Fig. 4C). These findings are consistent with a previous study in cell lines (Iwasaki et al., 1997) and strongly suggest a regulatory link between cAMP and glucocorticoids in the AVP cells. The AVP promoter contains CRE sites (Pardy et al., 1992; Iwasaki et al., 1997), and phosphorylated cAMP response element-binding protein is supposed to stimulate AVP gene transcription by binding to CRE sites (Kovács and Sawchenko, 1996). However, it is controversial whether glucocorticoid response elements (GREs) exist in the AVP promoter (Burke et al., 1997; Iwasaki et al., 1997). Even if the promoter does not contain negative GRE sites, glucocorticoids might interact with transcriptional factors to suppress gene transcription (Guardiola-Diaz et al., 1996; Iwasaki et al., 1997; Kovács, 1998; Malkoski and Dorin, 1999). Because DEX did not show significant effects on basal AVP mRNA expression in the presence of TTX (Fig. 2A), protein-protein interactions between GR and transcriptional factors activated by cAMP, rather than direct binding of GR to GRE, might be involved in the regulation of AVP gene transcription shown in the present study.

Glucocorticoids have been also implicated in the regulation of mRNA stability for many genes (Paek and Axel, 1987; Petersen et al., 1989; Lasa et al., 2001). Although the mechanisms by which glucocorticoids regulate the stability of mRNA are not well understood, 3' untranslated regions (UTRs) have been shown to play important roles in determining the degradation rates of mRNA (Garcia-Gras et al., 2000; Dodson and Shapiro, 2002). In contrast, cAMP is reported to cause elongation of poly(A) tail (Emanuel et al., 1998), upregulate several proteins that bind to 3' 
UTR (Skalweit et al., 2003), and increase the binding of the proteins to the $3^{\prime}$ UTR (Loflin and Lever, 2001). In the present study, glucocorticoids had inhibitory effects on AVP mRNA stability only when the stability was increased by cAMP. These data indicate that interactions between cAMP and glucocorticoids exist at not only the transcriptional but also the posttranscriptional level, although further study is necessary to elucidate the detailed mechanism.

It is noteworthy that the inhibitory effects of DEX on AVP gene expression were seen in the PVN but not in the SCN in the present study. The SCN is a center of circadian rhythm in mammals (Inouye and Kawamura, 1979; Reppert and Weaver, 2001), and AVP release and gene expression in the SCN are reported to show a circadian rhythm both in vivo and in vitro (Burbach et al., 1988; Ingram et al., 1998; Arima et al., 2002; Yambe et al., 2002). Previous studies have suggested that glucocorticoids, which are also known to show a circadian rhythm in the periphery (Mills, 1966; McNatty et al., 1972), might affect AVP neurons in the SCN (Robinson et al., 1983; Isobe and Isobe, 1998). Although our data do not exclude such a possibility, the clear differences in the effects of DEX on AVP gene expression between the PVN and the SCN suggest that glucocorticoids are not the major regulator of AVP gene expression in the SCN.

In conclusion, cAMP was able to increase AVP gene transcription and mRNA stability, and glucocorticoids inhibited AVP gene expression in the parvocellular neurons of the PVN. The mode of glucocorticoid action depends on whether cells are stimulated by cAMP, and regulatory interactions between cAMP and glucocorticoids in the AVP cell encompass both the gene transcription and mRNA stability.

\section{References}

Aguilera G (1994) Regulation of pituitary ACTH secretion during chronic stress. Front Neuroendocrinol 15:321-350.

Aguilera G, Pham Q, Rabadan-Diehl C (1994) Regulation of pituitary vasopressin receptors during chronic stress: relationship to corticotroph responsiveness. J Neuroendocrinol 6:299-304.

Antoni FA (1986) Hypothalamic control of adrenocorticotropin secretion: advances since the discovery of 41-residue corticotropin-releasing factor. Endocr Rev 7:351-378.

Arima H, Aguilera G (2000) Vasopressin and oxytocin neurones of hypothalamic supraoptic and paraventricular nuclei co-express mRNA for type- 1 and type- 2 corticotropin-releasing hormone receptors. J Neuroendocrinol 12:833-842.

Arima H, House SB, Gainer H, Aguilera G (2001) Direct stimulation of arginine vasopressin gene transcription by cAMP in parvocellular neurons of the paraventricular nucleus in organotypic cultures. Endocrinology 142:5027-5030.

Arima H, House SB, Gainer H, Aguilera G (2002) Neuronal activity is required for the circadian rhythm of vasopressin gene transcription in the suprachiasmatic nucleus in vitro. Endocrinology 143:4165-4171.

Baldino Jr F, O’Kane TM, Fitzpatrick-McElligott S, Wolfson B (1988) Coordinate hormonal and synaptic regulation of vasopressin messenger RNA. Science 241:978-981.

Burbach JPH, Liu B, Voorhuis TAM, Van Tol HHM (1988) Diurnal variation in vasopressin and oxytocin messenger RNAs in hypothalamic nuclei of the rat. Brain Res 464:157-160.

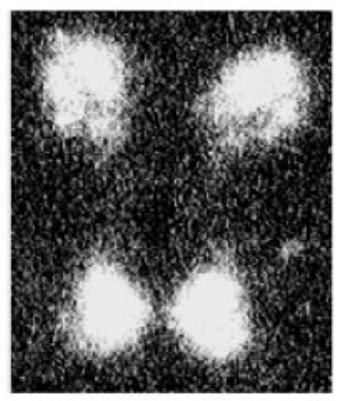

FSK

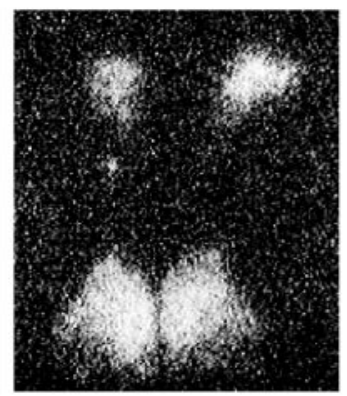

FSK

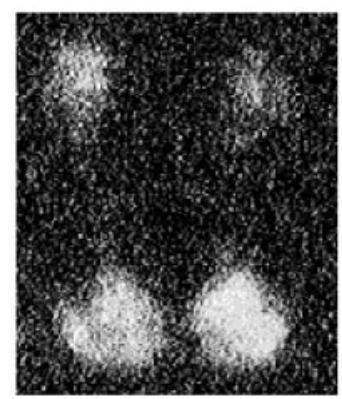

DEX

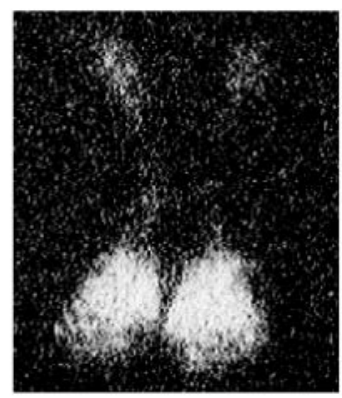

FSK+DEX

Burke ZD, Ho MY, Morgan H, Smith M, Murphy D, Carter D (1997) Repression of vasopressin gene expression by glucocorticoids in transgenic mice: evidence of a direct mechanism mediated by proximal 5 ' flanking sequence. Neuroscience 78:1177-1185.

Calogero AE, Gallucci WT, Chrousos GP, Gold PW (1988) Interaction between GABAergic neurotransmission and rat hypothalamic corticotropin-releasing hormone secretion in vitro. Brain Res 463:28-36.

Cole RL, Sawchenko PE (2002) Neurotransmitter regulation of cellular activation and neuropeptide gene expression in the paraventricular nucleus of the hypothalamus. J Neurosci 22:959-969.

Davis LG, Arentzen R, Reid JM, Manning RW, Wolfson B, Lawrence KL, Baldino Jr F (1986) Glucocorticoid sensitivity of vasopressin mRNA levels in the paraventricular nucleus of the rat. Proc Natl Acad Sci USA 83:1145-1149.

Decavel C, van den Pol AN (1992) Converging GABA- and glutamateimmunoreactive axons make synaptic contact with identified hypothalamic neurosecretory neurons. J Comp Neurol 316:104-116.

deGoeij DCE, Kvetnansky R, Whitnall MH, Jezova D, Berkenbosch F, Tilders FJH (1991) Repeated stress-induced activation of corticotropinreleasing factor neurons enhances vasopressin stores and colocalization with corticotropin-releasing factor in the median eminence of rats. Neuroendocrinology 53:150-159.

deGoeij DCE, Jezova D, Tilders FJH (1992) Repeated stress enhances vasopressin synthesis in corticotropin releasing factor neurons in the paraventricular nucleus. Brain Res 577:165-168.

Dodson RE, Shapiro DJ (2002) Regulation of pathways of mRNA destabilization and stabilization. Prog Nucleic Acid Res Mol Biol 72:129-164.

Emanuel RL, Girard DM, Thull DL, Majzoub JA (1992) Regulated expression of vasopressin gene by cAMP and phorbol ester in primary rat fetal hypothalamic cultures. Mol Cell Endocrinol 86:29-36.

Emanuel RL, Iwasaki Y, Arbiser ZK, Velez EM, Emerson CH, Majzoub JA (1998) Vasopressin messenger ribonucleic acid regulation via the protein kinase A pathway. Endocrinology 139:2831-2837.

Fuxe K, Wikström AC, Okret S, Agnati LF, Härfstrand A, Yu ZY, Granholm L, Zoli M, Vale W, Gustafsson JA (1985) Mapping of glucocorticoid receptor immunoreactive neurons in the rat tel- and diencephalon using a monoclonal antibody against rat liver glucocorticoid receptor. Endocrinology 117:1803-1812.

Garcia-Gras EA, Chi P, Thompson EA (2000) Glucocorticoid-mediated destabilization of cyclin D3 mRNA involves RNA-protein interactions in the $3^{\prime}$-untranslated region of the mRNA. J Biol Chem 275:22001-22008.

Gillies GE, Linton EA, Lowry PJ (1982) Corticotropin releasing activity of 
the new CRF is potentiated several times by vasopressin. Nature 299:355-357.

Guardiola-Diaz HM, Kolinske JS, Gates LH, Seasholtz AF (1996) Negative glucocorticoid regulation of cyclic adenosine 3',5'-monophosphatestimulated corticotropin-releasing hormone-reporter expression in AtT-20 cells. Mol Endocrinol 10:317-329.

Hellbach S, Gärtner P, Deicke J, Fischer D, Hassan AHS, Almeida OFX (1998) Inherent glucocorticoid response potential of isolated hypothalamic neuroendocrine neurons. FASEB J 12:199-207.

Herman JP, Cullinan WE, Young EA, Akil H, Watson SJ (1992) Selective forebrain fiber tract lesions implicate ventral hippocampal structures in tonic regulation of paraventricular nucleus corticotropin-releasing hormone $(\mathrm{CRH})$ and arginine vasopressin (AVP) mRNA expression. Brain Res 592:228-238.

Hillhouse EW, Milton NGN (1989) Effect of noradrenaline and $\gamma$-aminobutyric acid on the secretion of corticotropin-releasing factor-41 and arginine vasopressin from the rat hypothalamus in vitro. J Endocrinol 122:719-723.

House SB, Thomas A, Kusano K, Gainer H (1998) Stationary organotypic cultures of oxytocin and vasopressin magnocellular neurones from rat and mouse hypothalamus. J Neuroendocrinol 10:849-861.

Hu SB, Tannahill LA, Biswas S, Lightman SL (1992) Release of corticotrophin-releasing factor-41, arginine vasopressin and oxytocin from rat fetal hypothalamic cells in culture: response to activation of intracellular second messengers and to corticosteroids. J Endocrinol 132:57-65.

Ingram CD, Ciobanu R, Coculescu IL, Tanasescu R, Coculescu M, Mihai R (1998) Vasopressin neurotransmission and the control of circadian rhythms in the suprachiasmatic nucleus. Prog Brain Res 119:351-364.

Inouye SIT, Kawamura H (1979) Persistence of circadian rhythmicity in a mammalian hypothalamic "island" containing the suprachiasmatic nucleus. Proc Natl Acad Sci USA 76:5962-5966.

Isobe Y, Isobe M (1998) Circadian rhythm of Arg-vasopressin contents in the suprachiasmatic nucleus in relation to corticosterone. Brain Res 800:78-85.

Iwasaki Y, Oiso Y, Saito H, Majzoub JA (1997) Positive and negative regulation of the rat vasopressin gene promoter. Endocrinology 138:5266-5274.

Keim SR, Shekhar A (1996) The effects of $\mathrm{GABA}_{\mathrm{A}}$ receptor blockade in the dorsomedial hypothalamic nucleus on corticotrophin (ACTH) and corticosterone secretion in male rats. Brain Res 739:46-51.

Kim JK, Summer SN, Wood WM, Schrier RW (2001) Role of glucocorticoid hormones in arginine vasopressin gene regulation. Biochem Biophys Res Commun 289:1252-1256.

Kiss A, Aguilera G (1993) Regulation of the hypothalamic pituitary adrenal axis during chronic stress: responses to repeated intraperitoneal hypertonic saline injection. Brain Res 630:262-270.

Kovács KJ (1998) Functional neuroanatomy of the parvocellular vasopressinergic system: transcriptional responses to stress and glucocorticoid feedback. Prog Brain Res 119:31-43.

Kovács KJ, Mezey E (1987) Dexamethasone inhibits corticotropin-releasing factor gene expression in the rat paraventricular nucleus. Neuroendocrinology 46:365-368.

Kovács KJ, Sawchenko PE (1996) Sequence of stress-induced alterations in indices of synaptic and transcriptional activation in parvocellular neurosecretory neurons. J Neurosci 16:262-273.

Kovács K, Kiss JZ, Makara GB (1986) Glucocorticoid implants around the hypothalamic paraventricular nucleus prevent the increase of corticotropinreleasing factor and arginine vasopressin immunostaining induced by adrenalectomy. Neuroendocrinology 44:229-234.

Kovács KJ, Földes A, Sawchenko PE (2000) Glucocorticoid negative feedback selectively targets vasopressin transcription in parvocellular neurosecretory neurons. J Neurosci 20:3843-3852.

Lasa M, Brook M, Saklatvala J, Clark AR (2001) Dexamethasone destabilizes cyclooxygenase 2 mRNA by inhibiting mitogen-activated protein kinase p38. Mol Cell Biol 21:771-780.

Loflin P, Lever JE (2001) HuR binds a cyclic nucleotide-dependent, stabilizing domain in the $3^{\prime}$ untranslated region of $\mathrm{Na}^{+}$/glucose cotransporter (SGLT1) mRNA. FEBS Lett 509:267-271.

Ma XM, Aguilera G (1999) Differential regulation of corticotropinreleasing hormone and vasopressin transcription by glucocorticoids. Endocrinology 140:5642-5650.
Malkoski SP, Dorin RI (1999) Composite glucocorticoid regulation at a functionally defined negative glucocorticoid response element of the human corticotropin-releasing hormone gene. Mol Endocrinol 13:1629-1644.

Maurer JA, Wray S (1997a) Neuronal dopamine subpopulations maintained in hypothalamic slice explant cultures exhibit distinct tyrosine hydroxylase mRNA turnover rates. J Neurosci 17:4552-4561.

Maurer JA, Wray S (1997b) Luteinizing hormone-releasing hormone (LHRH) neurons maintained in hypothalamic slice explant cultures exhibit a rapid LHRH mRNA turnover rate. J Neurosci 17:9481-9491.

McNatty KP, Cashmore M, Young A (1972) Diurnal variation in plasma cortisol levels in sheep. J Endocrinol 54:361-362.

Miklós IH, Kovács KJ (2002) GABAergic innervation of corticotropinreleasing hormone $(\mathrm{CRH})$-secreting parvocellular neurons and its plasticity as demonstrated by quantitative immunoelectron microscopy. Neuroscience 113:581-592.

Mills JN (1966) Human circadian rhythms. Physiol Rev 46:128-171.

Oeding P, Schilling K, Schmale H (1990) Vasopressin expression in cultured neurons is stimulated by cyclic AMP. J Neuroendocrinol 2:859-865.

Otake K, Kondo K, Oiso Y (1991) Possible involvement of endogenous opioid peptides in the inhibition of arginine vasopressin release by $\gamma$-aminobutyric acid in conscious rats. Neuroendocrinology 54:170-174.

Paek I, Axel R (1987) Glucocorticoids enhance stability of human growth hormone mRNA. Mol Cell Biol 7:1496-1507.

Pardy K, Adan RAH, Carter DA, Seah V, Burbach JPH, Murphy D (1992) The identification of a cis-acting element involved in cyclic $3^{\prime}, 5^{\prime}$ adenosine monophosphate regulation of bovine vasopressin gene expression. J Biol Chem 267:21746-21752.

Petersen DD, Koch SR, Granner DK (1989) 3' noncoding region of phosphoenolpyruvate carboxykinase mRNA contains a glucocorticoid-responsive mRNA-stabilizing element. Proc Natl Acad Sci USA 86:7800-7804.

Plotsky PM, Otto S, Sutton S (1987) Neurotransmitter modulation of corticotropin releasing factor secretion into the hypophysial-portal circulation. Life Sci 41:1311-1317.

Reppert SM, Weaver DR (2001) Molecular analysis of mammalian circadian rhythms. Annu Rev Physiol 63:647-676.

Rivier C, Rivier J, Mormede P, Vale W (1984) Studies of the nature of the interaction between vasopressin and corticotropin-releasing factor on adrenocorticotropin release in the rat. Endocrinology 115:882-886.

Robinson AG, Seif SM, Verbalis JG, Brownstein MJ (1983) Quantitation of changes in the content of neurohypophyseal peptides in hypothalamic nuclei after adrenalectomy. Neuroendocrinology 36:347-350.

Sapolsky RM, Armanini MP, Packan DR, Sutton SW, Plotsky PM (1990) Glucocorticoid feedback inhibition of adrenocorticotropic hormone secretagogue release. Neuroendocrinology 51:328-336.

Sawchenko PE (1987a) Adrenalectomy-induced enhancement of CRF and vasopressin immunoreactivity in parvocellular neurosecretory neurons: anatomic, peptide, and steroid specificity. J Neurosci 7:1093-1106.

Sawchenko PE (1987b) Evidence for a local site of action for glucocorticoids in inhibiting CRF and vasopressin expression in the paraventricular nucleus. Brain Res 403:213-224.

Skalweit A, Doller A, Huth A, Kähne T, Persson PB, Thiele BJ (2003) Posttranscriptional control of renin synthesis identification of proteins interacting with renin mRNA $3^{\prime}$ - untranslated region. Circ Res 92:419-427.

Song Z, Sidorowicz HE, Sladek CD (2001) cAMP stimulation of vasopressin and oxytocin release and regulation of vasopressin mRNA stability: role of auto-facilitation. J Neuroendocrinol 13:158-165.

Swanson LW, Sawchenko PE (1983) Hypothalamic integration: organization of the paraventricular and supraoptic nuclei. Annu Rev Neurosci 6:269-324.

Uht RM, McKelvy JF, Harrison RW, Bohn MC (1988) Demonstration of glucocorticoid receptor-like immunoreactivity in glucocorticoid-sensitive vasopressin and corticotropin-releasing factor neurons in the hypothalamic paraventricular nucleus. J Neurosci Res 19:405-441.

Wray S, Kusano K, Gainer H (1991) Maintenance of LHRH and oxytocin neurons in slice explants cultured in serum-free media: effects of tetrodotoxin on gene expression. Neuroendocrinology 54:327-339.

Yambe Y, Arima H, Kakiya S, Murase T, Oiso Y (2002) Diurnal changes in arginine vasopressin gene transcription in the rat suprachiasmatic nucleus. Brain Res Mol Brain Res 104:132-136. 